\title{
The Effect on Growth of a Tax Shift between Land Value Taxes and Income Taxes in Denmark
}

\author{
Philip Allan, Gohar Hovsepyan \\ New Physiocratic League, Economic Research, Ottawa, Canada \\ Email: contact@newphy siocrats.org
}

How to cite this paper: Allan, P. and Hovsepyan, G. (2019) The Effect on Growth of a Tax Shift between Land Value Taxes and Income Taxes in Denmark. Modern Economy, 10, 1843-1850. https://doi.org/10.4236/me.2019.108119

Received: June 4, 2019

Accepted: August 4, 2019

Published: August 7, 2019

Copyright (อ 2019 by author(s) and Scientific Research Publishing Inc. This work is licensed under the Creative Commons Attribution International License (CC BY 4.0).

http://creativecommons.org/licenses/by/4.0/

\section{c) (i) Open Access}

\begin{abstract}
A land value tax (LVT) is different from a property tax in that it only taxes the underlying land, not the structure built on top of it. LVT is recognized by economists across the political spectrum, as the only tax raising significant revenue which theoretically does not diminish economic activity (and even increases it). This is in part because land is fixed and supply, and cannot be moved when taxed. An LVT instead encourages development of the land. This paper maps the ratio of LVT to other taxes in Denmark over time, and assesses its effect on economic growth. We can conclude that just as in theory, empirical evidence in the case of Denmark also shows positive results with regards to economic growth.
\end{abstract}

\section{Keywords}

Land Value Tax, Income Tax, Economic Policy, Political Economy, Tax Policy, Economic Growth

\section{Introduction}

The New Physiocratic League advocates for a platform to shift taxation away from personal \& corporate income taxation, and primarily towards a particular form of land value tax (LVT). It also advocates for anti-corruption measures and monetary reforms among other proposals. This study focuses specifically on the results of a shift to an LVT.

Empirical research on true Georgist policy, namely a tax system where the tax burden falls mainly on land, is limited due to a lack of real-world examples. The examples that have existed, mainly lack data. However, Denmark has an explicitly Georgist party which had success in parliament in the 1950s and helped 
implement a high national rate of land value tax where much of the tax burden existed at the time. Denmark provides a rare example where one can assess economic performance from this Georgist period, gradually transitioning to today where the tax burden falls mainly on incomes. While ample theoretical research exists on the implementation of an LVT, this study is the first of its kind to look at empirical data.

The remainder of this paper is organized as follows: In Section 2 the data and methods used in this study are presented. Section 3 includes stationary testing of time series. The estimated model and its checking are presented in Section 4 and Section 5, respectively. Concluding remarks are offered in the final section.

\section{Data Source and Methods}

All data for this study is taken from Statistics Denmark (the central authority on Danish statistics), and spans from 1966 to 2018. This brings to light another advantage of using LVT data from Denmark versus other countries using LVT, in that they have a fully complete set of tax and economic performance data.

The yearly data on gross domestic product (gdp), household consumption expenditure (housc), government consumption expenditure (gov), total taxes and duties (total_tax), total income taxes (income_tax), and land value taxes (lvt) in Denmark from 1966-2018 have been obtained ${ }^{1}$.

For analysis purposes, the following variables have been derived from the data: gdp growth rate $\left(g d p_{-} g r\right)$, household consumption expenditure growth rate $\left(c_{-} g r\right)$, government consumption expenditure growth rate $\left(g o V_{-} g r\right)$, the proportion of income tax in total taxes (inc_div_total), and the proportion of LVT in total taxes $\left(I_{v}\right.$ div_total $^{2}$. Below are the formulas:

$$
\begin{gathered}
g d p_{-} g r_{t}=\frac{g d p_{t}-g d p_{t-1}}{g d p_{t-1}} \\
c_{-} g r_{t}=\frac{\text { housc }_{t}-\text { housc }_{t-1}}{\text { housc }_{t-1}} \\
g o v_{-} g r_{t}=\frac{g v_{t}-g o v_{t-1}}{g o v_{t-1}} \\
\text { inc_div_total } t_{t}=\frac{\text { income_tax }_{t}}{\text { total_tax }_{t}} \\
\text { lvt_div_total } t_{t}=\frac{\text { lvt }_{t}}{\text { total_tax }_{t}}
\end{gathered}
$$

where $t$ stands for time period.

The summary statistics of the variables are presented in Table 1.

Furthermore, the time series under study have been tested for stationarity

\footnotetext{
${ }^{1}$ source: https://www.dst.dk/en [1].

${ }^{2}$ The proportion of taxes (not the absolute values) are used since it is very challenging to figure out if the change in absolute value is caused by economic activity change or some tax policy change [2].
} 
Table 1. Descriptive statistics of variables.

\begin{tabular}{ccccccc}
\hline Variables & Minimum & Maximum & Mean & Std. Dev. & Obs. & Units \\
\hline GDP & 82,414 & $2,218,323$ & $996,672.2$ & $672,478.5$ & 53 & DKK mln. \\
HOUSC & 47,300 & $1,016,800$ & $472,290.6$ & $301,185.2$ & 53 & DKK mln. \\
GOV & 14.800 & 546,500 & $249,154.7$ & $172,575.8$ & 53 & DKK mln. \\
LVT & 886.300 & $26,393,829$ & 984,9915 & $7,589,106$ & 53 & DKK 1000 \\
INCOME_TAX & 11.342 .022 & $6.44 \mathrm{E}+08$ & $2.79 \mathrm{E}+08$ & $2.02 \mathrm{E}+08$ & 53 & DKK 1000 \\
TOTAL_TAX & 2.445 .4941 & $1.01 \mathrm{E}+09$ & $4.55 \mathrm{E}+08$ & $3.20 \mathrm{E}+08$ & 53 & DKK 1000 \\
GDP_GR & -0.044035 & 0.158603 & 0.066248 & 0.043826 & 52 & - \\
GOV_GR & -0.010089 & 0.205882 & 0.073296 & 0.056574 & 52 & - \\
C_GR & 0.024393 & 0.183076 & 0.061662 & 0.044283 & 52 & - \\
INC_DIV_TOTAL & 0.459383 & 0.653027 & 0.588312 & 0.046240 & 53 & - \\
LVT_DIV_TOTAL & 0.016014 & 0.036242 & 0.023366 & 0.005699 & 53 & - \\
\hline
\end{tabular}

applying Augmented Dickey-Fuller (ADF) test, and an autoregressive distributed lag (ARDL) model has been estimated, with Eviews as the tool of choice.

\section{Testing for Stationarity}

To test the time series for stationarity ADF test has been applied. Otherwise, a time series that is nonstationary can only be studied on its behaviour only for a specific episode. Consequently, it will not be possible to generalize it for other time periods or making predictions ${ }^{3}$. The results are shown in Table 2.

The null hypothesis states that the variable under study has a unit root. As we can see, even at $10 \%$ significance level neither time series is stationary, except for gdp_gr and gov_gr. Therefore, the first order differences of nonstationary variables (d(c_gr), d(inc_div_total), d(lvt_div_total)) have been tested for unit roots. According to the results, the first order differences of all the nonstationary time series under study are stationary even at $1 \%$ significance level.

\section{Model Estimation}

To begin with, the best ARDL model based on Akaike information criterion (AIC) has been selected using automatic selection option in Eviews. ARDL (1, 0 , $0,4,0)$ model fits the data best according to AIC. The results are shown in Table 3.

According to the estimation results, some parameters are not statistically significant even at $10 \%$ level. Furthermore, the non-significant variables have been eliminated from the model. The estimation results of the new model are shown in Table 4.

As shown, now all parameters are statistically significant even at $1 \%$ significance level (except for the constant). Besides, Akaike information criterion has ${ }^{3}$ Gujarati, Damodar N., and Dawn C Porter. Basic Econometrics. 5th ed. Boston: McGraw-Hill, 2008 $[3]$. 
Table 2. Augmented Dickey-Fuller (ADF) test results for the time series under study ${ }^{4}$.

\begin{tabular}{lcc}
\hline $\begin{array}{l}\text { Null Hypothesis: Variable has a unit root } \\
\text { Exogenous: None } \\
\text { Lag Length: } 1 \text { (Automatic-based on AIC, maxlag }=4)\end{array}$ \\
\hline Variable & ADF test statistic & \\
\hline GDP_GR & $-1.684576^{*}$ & 0.0868 \\
C_GR & -1.297795 & 0.1769 \\
GOV_GR & $-2.089660^{* *}$ & 0.0364 \\
INC_DIV_TOTAL & 1.219252 & 0.9412 \\
LVT_DIV_TOTAL & -0.749168 & 0.3869 \\
D(C_GR) & $-8.183553^{* * *}$ & 0.0000 \\
D(INC_DIV_TOTAL) & $-6.118797^{* * *}$ & 0.0000 \\
D(LVT_DIV_TOTAL) & $-6.702513^{* * *}$ & 0.0000
\end{tabular}

Table 3. Estimation output.

Dependent Variable: GDP_GR

Sample (adjusted): 19712018

Model selection method: Akaike info criterion

Number of models evaluated: 2500

Selected Model: ARDL(1, 0, 0, 4, 0)

\begin{tabular}{ccccc}
\hline Variable & Coefficient & Std. Error & t-Statistic & Prob. \\
\hline GDP_GR(-1) & $0.351745^{* * *}$ & 0.123164 & 2.855897 & 0.0069 \\
D(INC_DIV_TOTAL) & $-4.742598^{* * *}$ & 1.710415 & -2.772776 & 0.0086 \\
D(LVT_DIV_TOTAL) & -0.121240 & 0.164615 & -0.736510 & 0.4659 \\
GOV_GR & $0.261008^{* *}$ & 0.097249 & 2.683908 & 0.0107 \\
GOV_GR(-1) & -0.077562 & 0.095713 & -0.810360 & 0.4228 \\
GOV_GR(-2) & 0.081657 & 0.096937 & 0.842368 & 0.4049 \\
GOV_GR(-3) & -0.028300 & 0.095203 & -0.297256 & 0.7679 \\
GOV_GR(-4) & $0.218668^{* *}$ & 0.083147 & 2.629906 & 0.0123 \\
D(C_GR) & $0.424335^{* * *}$ & 0.082776 & 5.126289 & 0.0000 \\
Constant & $0.007162^{*}$ & 0.004047 & 1.769503 & 0.0848 \\
R-squared (adj.) & & 0.885600 & & \\
S.E. of regression & & 0.014474 & & \\
F-statistic & & 0.000000 & \\
Prob(F-statistic) & & -5.449863 & & \\
AIC & & & & \\
\hline
\end{tabular}

been improved $(A I C=-5.58)$. For comparison purposes, the AIC for the previous model was -5.45

$4 * \star, * *$, and ${ }^{* * *}$ represent significance at the $10 \%(\mathrm{p}<0.1), 5 \%(\mathrm{p}<0.05)$, and $1 \%(\mathrm{p}<0.01)$ statistical levels, resprctively. 
Table 4. Estimation output.

\begin{tabular}{ccccc}
\hline $\begin{array}{c}\text { Dependent Variable: GDP_GR } \\
\text { Sample (adjusted): 1971 2018 }\end{array}$ & & & & \\
\hline Variable & Coefficient & Std. Error & t-Statistic & Prob. \\
\hline GDP_GR(-1) & $0.356995^{* * *}$ & 0.107863 & 3.309695 & 0.0019 \\
D(LVT_DIV_TOTAL) & $-4.803129^{* * *}$ & 1.457926 & -3.294495 & 0.0020 \\
GOV_GR & $0.230744^{* * *}$ & 0.066375 & 3.476384 & 0.0012 \\
GOV_GR(-4) & $0.216575^{* * *}$ & 0.072719 & 2.978236 & 0.0048 \\
D(C_GR) & $0.420686^{* * *}$ & 0.077568 & 5.423434 & 0.0000 \\
Constant & $0.007096^{*}$ & 0.003902 & 1.818386 & 0.0761 \\
R-squared (adj.) & & 0.892742 & & \\
S.E. of regression & & 0.014015 & & \\
F-statistic & & 79.23903 & & \\
Prob(F-statistic) & & 0.000000 & & \\
AIC & & -5.580910 & &
\end{tabular}

Thus, the estimated equation is:

$$
\begin{aligned}
G D P_{-} G R= & 0.36 * G D P_{-} G R(-1)+0.23 * G O V_{-} G R+0.22 * G O V_{-} G R(-4) \\
& -4.8 * D\left(L V T_{-} \text {DIV_TOTAL }\right)+0.42 * D\left(C_{-} G R\right)+0.007
\end{aligned}
$$

That is, the GDP growth rate in Denmark at time $t, G D P_{-} G R$, is explained by its value at time $t-1$, by the rate of change of government expenditure at timet and $t-4$, by the difference of LVT ratio at time $t$, and by the difference of household consumption expenditure change rate at time $t$.

It is worth noticing that the difference of LVT ratio at time $t$ has a negative impact on GDP growth rate for the same period of time.

\section{Model Diagnostic Checking}

The estimated residuals from the regression have been tested for autocorrelation. As we can see from Figure 1 all values of the correlogram are within the boundaries. To conclude, we fail to reject the null of no autocorrelation between the residuals. So there are no significant autocorrelations between residuals according to the ACF plot.

Furthermore, the errors normality and homoscedasticity assumptions have been checked.

The results are as follows:

As shown above in Figure 2, at 5\% significance level the residuals do not appear to be normally distributed (null hypothesis: errors are normally distributed).

The output above (Table 5) suggests not rejecting the null of homoskedasticity at $5 \%$ significance level. So, we can conclude there is no heteroskedasticity. 


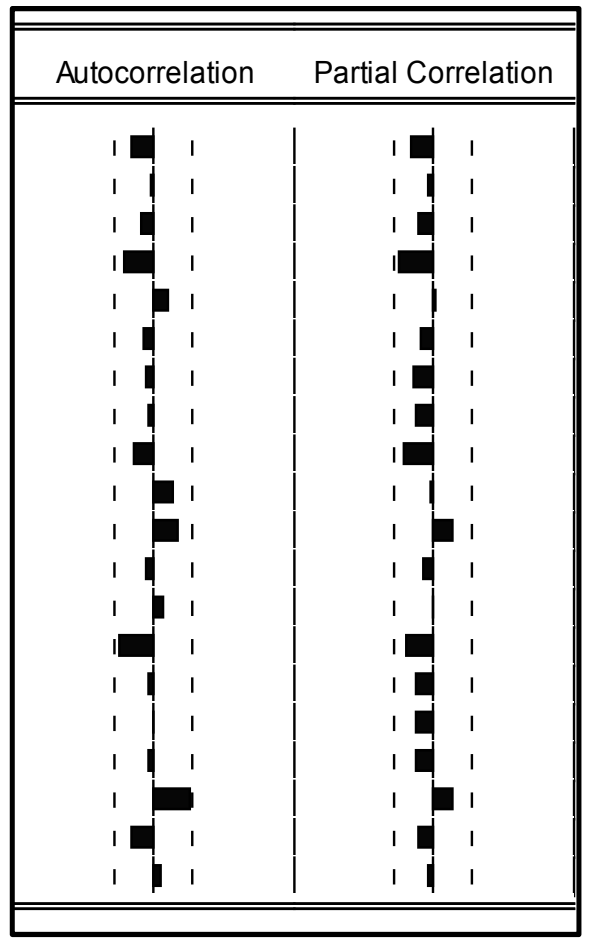

Figure 1. Correlogram of residuals.

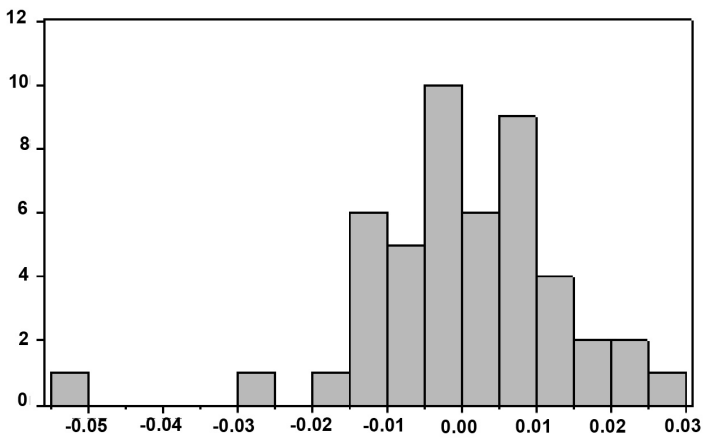

\begin{tabular}{lc}
\hline Series: Residulas & \\
\hline Mean & $-1.19 \mathrm{E}-18$ \\
Std. Dev. & 0.013249 \\
Jarque-Bera & 26.97791 \\
Probability & 0.000001 \\
\hline
\end{tabular}

Figure 2. Jarque-Bera normality test for residuals.

Table 5. Test for Heteroskedasticity.

\begin{tabular}{cccc}
\hline \multicolumn{4}{c}{$\begin{array}{c}\text { Heteroskedasticity Test: White } \\
\text { Null hypothesis: Homoskedasticity }\end{array}$} \\
\hline F-statistic & 1.791272 & Prob. F (20,27) & 0.0788 \\
Obs ${ }^{\star}$ R-squared & 27.37141 & Prob. Chi-Square (20) & 0.1251 \\
Scaled explained SS & 53.31813 & Prob. Chi-Square (20) & 0.0001 \\
\hline & Heteroskedasticity Test: Breusch-Pagan-Godfrey & \\
\hline F-statistic & Null hypothesis: Homoskedasticity & 0.1562 \\
Obs ${ }^{\star}$ R-squared & 1.698014 & Prob. F (5,42) & 0.1523 \\
Scaled explained SS & 8.071355 & Prob. Chi-Square (20) & 0.0077 \\
\hline
\end{tabular}


Table 6. Serial correlation LM test.

Breusch-Godfrey Serial Correlation LM Test

Null hypothesis: No serial correlation at up to 4 lags

\begin{tabular}{cccc}
\hline F-statistic & 1.279533 & Prob. F (4,38) & 0.2951 \\
Obs $^{*}$ R-squared & 5.697611 & Prob. Chi-Square (4) & 0.2229 \\
\hline
\end{tabular}

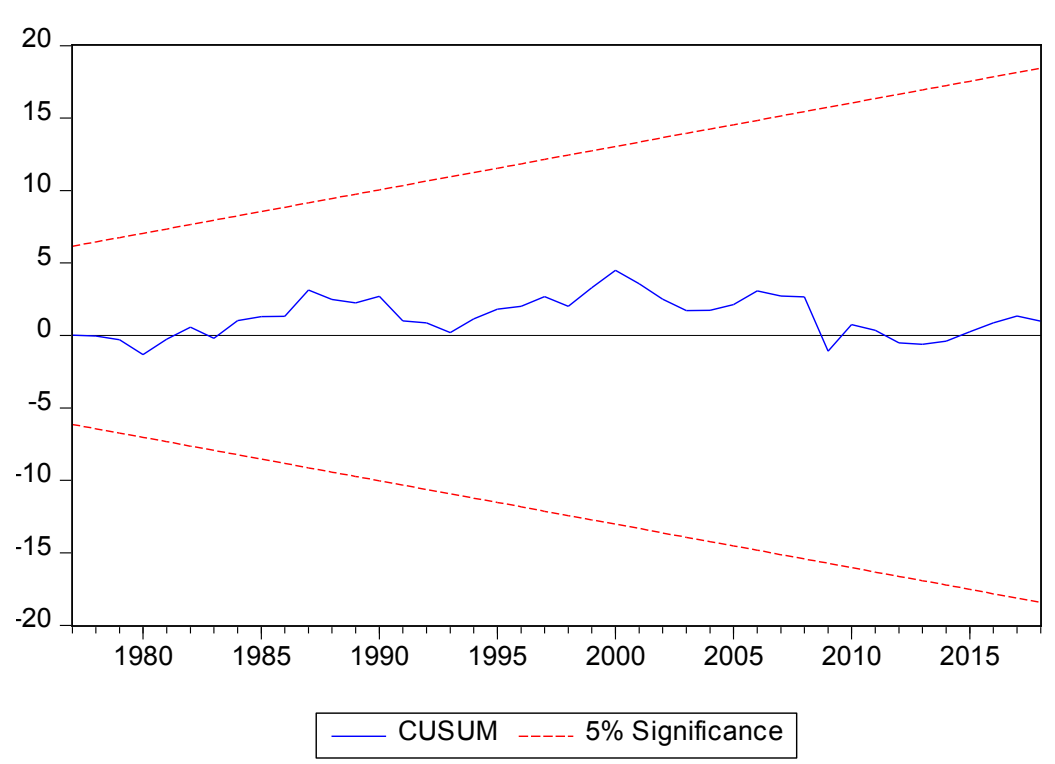

Figure 3. CUSUM test.

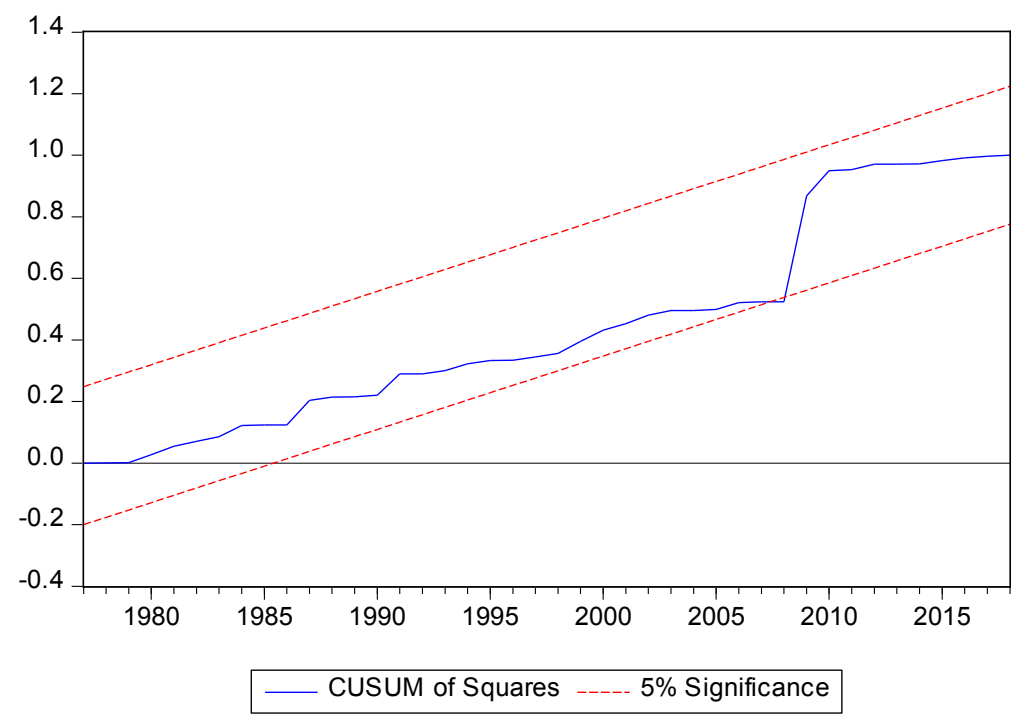

Figure 4. CUSUM of squares test.

Table 6 results reveal that the Breusch-Godfrey Serial Correlation LM Test ${ }^{5}$ fails to reject the null at $5 \%$ significance level.

Furthermore, the cumulative sum of recursive residuals (CUSUM) and the ${ }^{5}$ In this case the Durbin-Watson statistic is not applicable as we a have lagged dependent variables on the right side of the model. 
CUSUM of squared residuals (CUSUMSQ) tests have been applied in order to test for the stability of the estimated parameters.

Figure 3 clearly indicates no coefficient instability in the equation during the sample period as the cumulative sum is inside the $5 \%$ critical lines. Likewise, Figure 4 shows that the cumulative sum of squares is also within the $5 \%$ critical lines, suggesting that the residual variance is stable.

\section{Conclusion}

A shift towards a land value tax is the only solution to many of the growth and taxation issues governments are facing. However, it is important that tax reform is delivered in as few packages as possible, as the economy appears to respond best when tax rates are predictable, as in Denmark. The LVT-based platform offered by the New Physiocratic League, if implemented, would best ensure real progress if put into place quickly, and then allowed the economy time to reorient itself towards its new trajectory of sustainable yet stronger growth.

\section{Conflicts of Interest}

The authors declare no conflicts of interest regarding the publication of this paper.

\section{References}

[1] https://www.dst.dk/en

[2] Allan, P. (2018) The New School of Economics: The Platform and Theory Behind the New Physiocrats, Amazon Europe, Warsaw.

[3] Gujarati, Damodar, N. and Porter, D.C. (2008) Basic Econometrics. 5th Edition, McGraw-Hill, Boston. 